\title{
Fruit and Hormones Influence Flowering of Apple. I. Effect of Cultivar
}

\author{
Joann M. McLaughlin and Duane W. Greene \\ Department of Plant and Soil Sciences, University of Massachusetts, Amherst, MA 01003
}

Additional index words. Malus domestics, cytokinins, daminozide

Abstract. Fruit-bearing limbs of five apple (Malus domestics Borkh.) cultivars varying in degree of biennial bearing were either unsprayed or received five repeat applications of BA at $50 \mathrm{mg} \cdot \mathrm{liter}^{-1}$ with daminozide at $2000 \mathrm{mg} \cdot \mathrm{liter}^{-1}$. BA and daminozide increased early appendage formation of potential flower buds, but this increase was sustained only on 'Early McIntosh' and 'Baldwin'. BA and daminozide increased return bloom on all treated limbs, with the exception of 'Early McIntosh'. The annually bearing cultivars McIntosh and Delicious initiated 20 appendages before the formation of floral parts, while the biennially bearing cultivars Golden Delicious, Baldwin, and Early McIntosh initiated 19, 18, and 22 appendages, respectively. Flower removal before bloom increased appendage formation on the biennial cultivar Baldwin but not on the annual cultivar Delicious. Chemical names used: $N$-(phenylmethyl) $-1 \mathrm{H}$ purine-6-arnine (BA); butanedioic acid mono(2,2-dimethyihydrazide) (daminozide).

Apples originate from an inflorescence of usually five to six flowers that are located terminally on shortened shoots or spurs (Abbott, 1970; Bijihouwer, 1924). Vegetative buds are formed in the axils of leaves below flower primordia, of which two are usually initiated at the time of flowering. The following spring, one of the two vegetative buds will usually become active and, if conditions are favorable, will be the site of flower bud formation for that spur during late summer. Following dormancy in the spring but before the time of flower formation, the apex of the vegetative bud (bourse bud) will initiate leaf-like primordia (appendages) that mature and develop over the season to form the budscales. transition leaves, and true leaves of a mature vegetative or reproductive bud (Fig. 1). Budscales are initiated first by the apex of the bourse bud followed by the transition leaves, true leaves, and bracts.

Two types of leaves are found on fruit-bearing spurs. Primary leaves are true leaves that form part of the inflorescence that subtend the fruit, whereas secondary leaves are formed later as the bourse bud/shoot grows (Fig. 1). Fulford (1966a) suggested that the rate of appendage formation determined whether flowers formed in the bourse bud. If the plastochron, i.e., the time interval between initiation of appendages, is too long, no flowers form. Fulford (1966b) found that fruit slowed the plastochron to 18 days in the bourse buds of biennially bearing cultivars, whereas a 7-day plastochron was found in the bourse buds of annually bearing cultivars.

Previously, BA used alone or in combination with daminozide increased return bloom on heavy-bearing 'Golden Delicious' apple trees (McLaughlin and Greene, 1984). We suggested that BA acted by counteracting the inhibitory influence of fruit on flowering. Daminozide has been used commercially to encourage repeat bloom in biennially bearing cultivars.

This investigation was initiated to document the effect of BA and daminozide on appendage and flower bud formation. Cultivars displaying a range of biennial bearing tendency were selected to determine if there is a relationship between the rate of appendage formation and biennial bearing.

Received for publication 6 Nov. 1989. Paper no. 2944 Massachusetts Agricultural Experiment Station, Univ. of Massachusetts, Amherst. This research was supported in part by Experiment Station Project no. 609. The cost of publishing this paper was defrayed in part by the payment of page charges. Under postal regulations, this paper therefore must be hereby marked advertisement solely to indicate this fact.

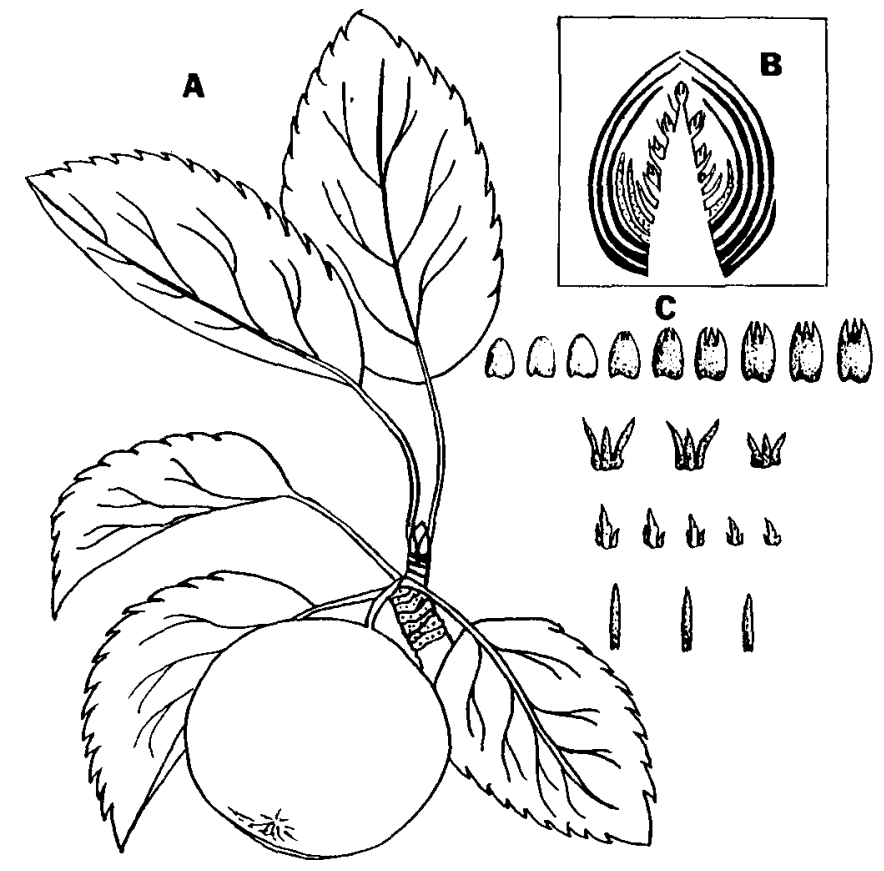

Fig. 1. (A) Representative diagram of an apple spur late in the growing season when flowers have been initiated in the bourse bud. (B) Cross section illustration through a bourse bud. From outer to inner appendages: thick solid structures $=$ budscales, flecked structures $=$ transition leaves, unflecked structures $=$ true leaves, and thin lines = bracts (Abbott, 1970). The small bud in the axil of the true leaf is vegetative, while all others are flower buds. (C) Representative illustration of specific types of appendages (budscales, transition leaves, true leaves, and bracts).

\section{Materials and Methods}

Flowers and plant growth regulators. (Expt. 1). Six mature trees each of five cultivars that had an increasing tendency toward biennial bearing were selected: 'Cornell McIntosh', 'Vance Delicious', 'Golden Delicious', 'Early McIntosh', and 'Baldwin'. Two uniform limbs, 12 to $15 \mathrm{~cm}$ in circumference, on each tree of each cultivar were selected before bloom and randomly assigned to either 1) + flowers, no plant growth regulator (PGR) treatment; and 2) + flowers, + PGR treatment. PGR treatments were BA at $50 \mathrm{mg} \cdot$ liter $^{-1}$ applied to the drip point at full bloom (FB) $+3,+22$, and +43 days; daminozide was applied at 2000 
$\mathrm{mg} \cdot$ liter $^{-1}$ to the drip point only at $\mathrm{FB}+3$ days. Buffer-X at $0.01 \%$ was included when BA was applied alone. Treatments were arranged in a randomized complete-block design with six replications.

Five spurs on each tagged limb were collected at $\mathrm{FB}+1$, $+6,+19,+24$, and +37 days and stored in formalin : $70 \%$ ethyl alcohol : acetic acid (FAA) (10:50:5, by volume) solution until dissected using a stereoscopic microscope. Two of the five spurs collected from each of the six replications were initially dissected. The number of fruit or flowers on the spur, the number of secondary leaves on the bourse bud, and the number of leaf-like appendages initiated in the bourse bud on these spurs were counted on a particular 'date. Ten additional spurs were collected from each cultivar in late September, and the number and the type of appendages initiated before the appearance of flower parts were counted. Before bloom the following year, the number of vegetative and flowering spurs on the tagged limbs was counted and flowering was expressed as the percentage of spurs that formed flowers.

Flower removal. (Expt. 2). Two limbs on each of six trees were selected before bloom in 1985 on the annually bearing 'Red Prince Delicious' and the biennially bearing 'Baldwin'. All flowers were removed ( - flowers) from one limb 7 to 9 days before full bloom on 'Delicious' and 'Baldwin' and all flowers were allowed to remain ( + flowers) on the second limb. Treatments were arranged in a randomized complete-block design with six replications. Five spur samples on each of the six replications were collected at FB $-2,,+1,+4,+7,+10$, and +20 days, and stored in FAA solution. Two of the five spurs were dissected and the number of leaf-like appendages was counted.

Square-root transformations were performed on the number of appendages, secondary leaves, and fruit. Treatment means within period and cultivar were separated by Duncan's multiple range test at $P=0.05$, using a pooled interaction and main factor error term for period, and a whole-plot error term for bloom.

\section{Results}

BA and daminozide sprays had increased the number of appendages on 'Baldwin', 'Delicious', 'McIntosh', and 'Early McIntosh' at FB +19 days relative to the controls (Table 1). At the last sampling date, only spurs of 'Early McIntosh' and 'Baldwin' treated with BA and daminozide had more appendages than nontreated spurs. The appendage count was increased very early, at $\mathrm{FB}+6$ days, on $\mathrm{BA}-$ and daminozide-treated spurs of 'Baldwin'. This increase in number of appendages continued until $\mathrm{FB}+19$ days. A second application of BA at FB +22 days caused another increase in the appendage count on spurs that were harvested at $\mathrm{FB}+37$ days. BA and daminozide application to spurs of 'Early McIntosh' increased the number of appendages over control spurs at FB +19 days, a trend that continued over the measurement period. There were no statistical differences between treatments in the number of appendages on 'Golden Delicious', 'Delicious', and 'McIntosh', but there was a trend toward increased appendages on treated limbs at $\mathrm{FB}+24$ and $\mathrm{FB}+37$ days.

BA and daminozide increased return bloom (percent flowering spurs) on all treated limbs with the exception of 'Early McIntosh' (Fig. 2). In general, return bloom on fruit-bearing spurs of the strongly biennially bearing cultivars was less than that on the annually bearing cultivars.

The total number of appendages initiated before formation of the first flower parts, the sepals, varied among cultivars (Table 2). The annually bearing cultivars McIntosh and Delicious initiated 20 appendages while the biennial-bearing cultivars Golden Delicious, Baldwin, and Early McIntosh initiated 19, 18, and 22 appendages, respectively. Although there was some variability in the number of specific types of appendages formed by

Table 1. Effects of growth regulators on number of appendages on fruiting spurs of five apple cultivars. ${ }^{2 . y}$

\begin{tabular}{|c|c|c|c|c|c|}
\hline \multirow{2}{*}{$\begin{array}{l}\text { Cultivar and } \\
\text { treatment }\end{array}$} & \multicolumn{5}{|c|}{ Appendages/spur [days after full bloom (FB)] } \\
\hline & $\mathrm{FB}+1$ & $\mathrm{FB}+6$ & $\mathrm{FB}+19$ & $\mathrm{FB}+24$ & $\mathrm{FB}+37$ \\
\hline \multicolumn{6}{|l|}{ Delicious } \\
\hline Control & $\begin{array}{l}6.8 \\
\text { NS }\end{array}$ & $\begin{array}{l}8.3 \\
\text { NS }\end{array}$ & $10.6 *$ & $\begin{array}{l}12.0 \\
\text { NS }\end{array}$ & $\begin{array}{l}13.9 \\
\text { NS }\end{array}$ \\
\hline $\begin{array}{c}\text { BA50 + D2000 } \\
\text { Baldwin }\end{array}$ & 6.8 & 8.5 & 11.3 & 12.3 & 14.3 \\
\hline Control & $\begin{array}{l}5.9 \\
\text { NS }\end{array}$ & 7.3 & 9.8 & ${ }_{\mathrm{NS}}^{12.2}$ & 13.4 \\
\hline$\underset{\text { McIntosh }}{\text { BA50 + D2000 }}$ & 5.9 & 6.3 & 11.4 & 12.7 & 14.3 \\
\hline Control & $\begin{array}{l}7.6 \\
\text { NS }\end{array}$ & $\begin{array}{l}8.8 \\
\text { NS }\end{array}$ & 11.0 & $\begin{array}{l}11.9 \\
\text { NS }\end{array}$ & $\begin{array}{l}14.1 \\
\text { NS }\end{array}$ \\
\hline $\begin{array}{l}\text { BA50 + D2000 } \\
\text { Early McIntosh }\end{array}$ & 7.5 & 9.2 & 11.6 & 12.3 & 14.7 \\
\hline $\begin{array}{l}\text { Early McIn } \\
\text { Control }\end{array}$ & $\begin{array}{l}7.8 \\
\text { NS }\end{array}$ & $\begin{array}{l}9.1 \\
\text { NS }\end{array}$ & 12.3 & 12.8 * & 14.1 \\
\hline $\begin{array}{l}\text { BA50 + D2000 } \\
\text { Golden Delicious }\end{array}$ & 7.8 & 9.4 & 13.3 & 13.8 & 15.2 \\
\hline Control & $\begin{array}{l}6.9 \\
\mathrm{~N}\end{array}$ & $\begin{array}{l}8.4 \\
\text { NS }\end{array}$ & $\begin{array}{l}10.0 \\
\text { NS }\end{array}$ & $\begin{array}{l}11.0 \\
\text { NS }\end{array}$ & $\begin{array}{l}12.0 \\
\text { NS }\end{array}$ \\
\hline $\mathrm{BA} 50+\mathrm{D} 2000$ & 7.0 & 8.3 & 9.9 & 11.3 & 12.5 \\
\hline
\end{tabular}

${ }^{2}$ Benzyladenine (BA) was applied at $50 \mathrm{mg} \cdot \operatorname{lite}^{-1}$ with $0.01 \%$ Buffer- $\bar{X}^{-}$at $\overline{\text { FB }}$ $+3,+22$, and +43 days. Daminozide (D) was applied at $2000 \mathrm{mg} \cdot 1$ iter $^{-1}$ at $\mathrm{FB}+3$ days.

${ }^{\gamma}$ Data are a mean of 12 observations.

*,Ns Significant at $P=0.05$, or nonsignificant. 


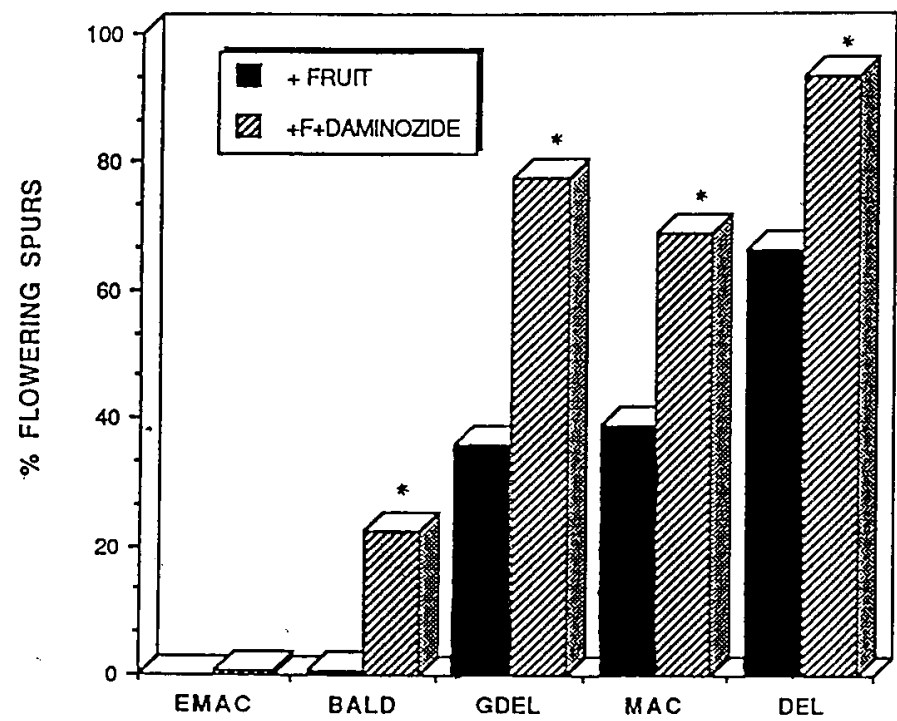

Fig. 2. Effect of growth regulators on return bloom (percent flowering spurs) on spurs of 'Early McIntosh' (EMAC); 'Baldwin' (BALD); 'Golden Delicious' (GDEL); 'McIntosh' (MAC); and 'Delicious' (DEL) apple. * Indicates significant difference within cultivar by Duncan's multiple range test, $P=0.05$.

Table 2. Number and type of appendage initiated on spurs of several apple cultivars before formation of flower parts.

\begin{tabular}{|c|c|c|c|c|c|}
\hline \multirow[b]{2}{*}{ Cultivar } & \multicolumn{5}{|c|}{ No./spur } \\
\hline & $\begin{array}{c}\text { Bud } \\
\text { scales }\end{array}$ & $\begin{array}{c}\text { Transition } \\
\text { leaves }\end{array}$ & $\begin{array}{c}\text { True } \\
\text { leaves }\end{array}$ & Bracts & Total \\
\hline McIntosh & 9 & 3 & 5 & 3 & 20 \\
\hline Delicious & 9 & 3 & 5 & 3 & 20 \\
\hline
\end{tabular}

${ }^{2}$ Data are a mean of 10 observations.

individual cultivars (budscales, transition leaves, and true leaves), the total number of appendages initiated by each cultivar before sepal formation did not vary.

From $\mathrm{FB}-2$ days to $\mathrm{FB}+4$ days, the biennially bearing cultivar Baldwin initiated appendages at a similar rate in spurs on the + fruit and - fruit limbs (Fig. 3). However, from FB +4 days to $\mathrm{FB}+7$ days, spurs on fruit-bearing limbs did not initiate any appendages. In contrast, spurs on defruited limbs continued to initiate appendages during that interval and, consequently, they had more appendages by $\mathrm{FB}+7$ days. From $\mathrm{FB}+7$ days onward, the number of appendages remained greater in spurs from limbs lacking fruit than in spurs on limbs with fruit, although the rate of appendage initiation proceeded similarly. The number and rate of appendage formation in 'Delicious' was similar regardless of the presence of fruit.

\section{Discussion}

Fulford (1966b) first observed that fruit of biennially bearing cultivars influence the rate of appendage initiation. His observation was confirmed in this investigation. Fruit of 'Baldwin' inhibited appendage initiation in the bourse bud, whereas fruit of 'Delicious' did not inhibit appendage initiation. Further, cultivars differ not only in the influence fruit have on appendage formation, but also in the kinetics of inhibition. Bourse buds of 'Baldwin' were inhibited by the fruit from $\mathrm{FB}+4$ to $\mathrm{FB}+7$

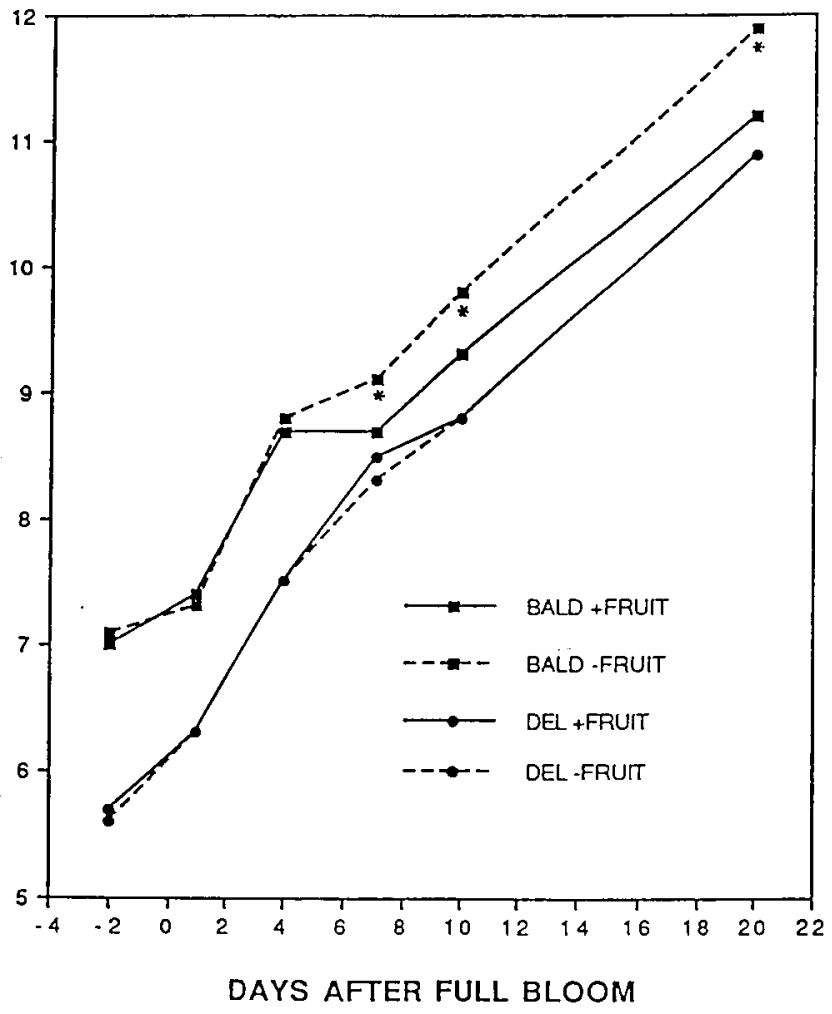

Fig. 3. Effect of fruit on appendage number on spurs of 'Baldwin' (BALD); and 'Delicious' (DEL) apple. * Indicates significant difference by Duncan's multiple range test, $P=0.05$. See Fig. 1 for illustration of an apple spur bud late in the season when flowers have been initiated in the Bourse bud as shown in box.

days, in contrast to bourse buds of 'Early McIntosh', which were inhibited 20 to 25 days after FB (McLaughlin and Greene, 1991). Fulford (1966b) related these differences in the interval that influences appendage formation to the time the cultivar was harvested. The earlier inhibition of appendage initiation was observed, the earlier the cultivar was harvested. This was not confirmed in this investigation. Fruit of 'Baldwin' are normally harvested in mid-October, whereas fruit of 'Early McIntosh' are harvested in early to mid-August.

Cultivars varied considerably in both the rate and time of initiation of appendages on spurs carrying fruit (Table 1). There were more appendages on 'McIntosh' spurs than on 'Delicious' spurs, but these differences disappeared by $\mathrm{FB}+24$ days. There were more appendages on 'Baldwin' than on 'Golden Delicious' at FB +24 days, whereas the opposite was true at $\mathrm{FB}+1$ day.

Fulford (1965) suggested that the rate of appendage initiation at the apex was governed solely by the influence of the surrounding appendages, thus accounting for long periods of stability in the plastochron. However, in this investigation, the rate of primordia production varied within and between cultivars, indicating a more independent role of the apex in controlling primordia production. Appendages appear as small bumps on the apex as they are initiated. Their ultimate developmental forms are probably determined by interactions with other appendages, as described by Fulford (1965) and others (Barlow, 1962; Snow and Snow, 1959) but the rate of initiation appeared to be independent of these interactions and also independent of flower initiation.

The effects of BA and daminozide on return bloom were variable (Fig. 2), some of which we believe is due to thinning by growth regulator sprays. BA and daminozide increased return 
bloom on all cultivars except 'Early McIntosh'. Although final fruit set was not determined in this experiment, we noted that some treatments caused fruit thinning on some cultivars. Since daminozide is not thought to thin, the thinning effect must have been due to BA applications (Greene and Autio, 1989). Most of the fruit were thinned from 'Baldwin', 'Delicious', and 'Golden Delicious'. Some thinning also occurred on 'McIntosh', but little on 'Early McIntosh'.

There was no relationship between the number of appendages formed before flowering and the degree of biennial bearing (Table 2). 'Baldwin', the most biennial, initiated 18 appendages ,before flowers were formed, and 'Early McIntosh' initiated 22, whereas the two least biennial cultivars, McIntosh and Delicious, initiated 20. Environment, growing conditions, or discrepancies in the method of counting may explain differences in reported numbers of appendages produced before flower parts are initiated. Luckwill and Silva (1979) reported 21 appendages for 'Golden Delicious' grown in Great Britain, but in Massachusetts 19 appendages were found for 'Golden Delicious'. 'Cox's Orange Pippin', similar to 'McIntosh' and 'Delicious' in tendency toward biennial bearing, also initiated 20 appendages before actual flower parts were produced.

The number of nodes produced by a meristem before the formation of a terminal flower is tightly controlled (Jegla and Sussex, 1979; Seltmann, 1974; Thomas et al., 1975). In apple, the number of nodes produced varies with cultivar. The critical period appears to be after initiation of the last true leaf and before initiation of the first bract. During that period, transition to the reproductive state occurs (M. Goffinett, personal communication; Pratt et al., 1959). Thus, the rate appendages are initiated may not be a critical factor in determining the initiation of flowers. Instead, it appears that the meristem must first reach the critical node number by a certain time and then the meristem must still have the capacity to initiate flowers. Fruit may influence the rate at which the meristem reaches the critical number of nodes and once the critical number has been reached, fruit may also influence the ability of the meristem to initiate flowers.

\section{Literature Cited}

Abbott, D.L. 1970. The role of budscales in the morphogenesis of the apple fruit bud, p. 65-80. In: L.C. LuckWill and C.V. Cutting (eds.). Physiology of tree crops. Academic, New York.

Barlow, H.W.B. 1962. The influence of the leaf upon the development of its axillary merisem. Rpt. E. Malling Res. Sta. 1961. p. 71-76.

Bijihouwer, J. 1924. De periodiciteit van de kuopont wikkeling bij denappel. Mededlingen Landouvkeogeschool de Wageningen-Nederland 27:1-64.

Fulford, R.M. 1965. The morphogenesis of apple buds. I. The activity of the apical meristem. Ann. Bet. 29:167-180.

Fulford, R.M. 1966a. The morphogenesis of apple buds. III. The inception of flowers. Ann. Bot. 30:207-219.

Fulford, R.M. 1966b. The morphogenesis of apple buds. IV. The effect of fruit. Ann. Bet. 30:597-606.

Greene, D.W. and W.R. Autio. 1989. Evaluation of benzyladenine as a chemical thinner on 'McIntosh' apples. J. Amer. Soc. Hort. Sci. 114:68-73.

Jegla, D.E. and I.M. Sussex. 1987. Clonal analysis of meristem development, p. 101-120. In: J.G. Atherton (cd.). Manipulation of flowering. Butterworths, London.

LuckWill, L.C. and J.M. Silva. 1979. The effects of daminozide and gibberellic acid on flower initiation, growth, and fruiting of apple CV. Golden Delicious. J. Hort. Sci. 54:217-223.

McLaughlin, J.M. and D.W. Greene. 1984. Effects of BA, GA ${ }_{4+7}$, and daminozide on fruit set, fruit quality, vegetative growth, flower initiation, and flower quality of 'Golden Delicious' apple. J. Amer. Soc. Hort. Sci. 109:34-39.

McLaughlin, J.M. and D.W. Greene. 1991. Fruit and hormones influence flowering of apple. II. Effects of hormones. J. Amer. Soc. Hort. Sci. 116(3):450-453.

Pratt, C., J. Einset, and M. Zahur. 1959. Radiation damage in apple shoot apices. Amer. J. Bet. 46:537-544.

Snow, M. and R. Snow. 1959. Regulation of sizes of leaf primordia by older leaves. Proc. Royal Soc. 151:39-47.

Seltmann, H. 1974. Effect of light periods and temperature on plant form of Nicotiana tabacum CV. Hicks. Bet. Gaz. 136:196-200.

Thomas, J. F., C.F. Anderson, C.D. Raper, and R.J. Downs. 1975. Time of floral initiation in tobacco as a function of temperature and photoperiod. Can. J. Bet. 53:1400-1410. 